\title{
Appllication of Marketing Concept in the Hospitality and Tourism Industry in Akwa Ibom State, Nigeria: An Evauation
}

\author{
Okokon Attih \\ Department of Marketing, Faculty of Social \& Management Sciences Akwa Ibom State University, P.M.B. \\ 1167, Uyo, Obio - Akpa Campus, Oruk Anam L.G..A., Akwa Ibom State, Nigeria.
}

\begin{abstract}
Hospitality and tourism industry comprises businesses involve in the provision of accommodations, foods, recreational centers for visitors or travelers, comfort and catering services for others. The purpose of this paper was to identify and examine the benefits to be derived when marketing concept is applied effectively in the hospitality and tourism industry. The paper was based on descriptive research design. The article analyses marketing variables and how they influence customer patronages. Some recommendations made include, the operators of the hospitality and tourism industry should apply the marketing concept effectively to have an edge over its competitors, they should embrace the concept for a better economic gain to the organization, experts in the field of marketing should be employed to ensure effective an efficient application of the marketing concept. Keywords: marketing concept, Hospitality, Tourism, Akwa Ibom State, Nigeria.
\end{abstract}

\section{Introduction}

The application of the basic principles of marketing is the same irrespective of whether one is marketing tangible or intangible goods for commercial (profit) or non - commercial (social) organizations. The marketing of services which is something called marketing of professional services cuts across the hospitality and tourism industry etc. According to Chigozie (2007), marketing must not be seen narrowly as the task of finding clever ways to set a hostel's products or services. According to him many people confuse marketing with some of its sub - functions such as advertising and selling. Marketing is not the art of selling what you make but knowing what to make, it is the art of identifying and understanding customer needs and creating solution that deliver satisfaction to the customers, profit to hostel, fast food, restaurant operators and tourism business etc.

Hospitality and tourism industry is the sector that the Federal, States and Local Governments pays a lot of attention to, by a successive government in Nigeria. Various governments seem o recognize the potentials of hospitality and tourism industry to boost the economy and corporate image of the country in a variety of ways.

Based on this, marketing in hospitality and tourism world critically look at the dynamic of the environment encompasses in business, physical (geographical) and governmental policies environment, (Adeyemo, 2005). The philosophy of marketing in the hospitality and tourism industry is customer oriented. Their services are defined from the customers' point of view. Hospitality means to be hospitable, Akwa Ibom State people in Nigeria by nature are hospitable and accommodating. This quality should be exhibited in our hospitality and tourism industry, (Nwidum, 2007).

\section{Theoretical and Conceptual Overview of Marketing Concept}

In today's competitive business environment, realizing that a firm cannot successfully operate using production, product or sales concept as a guiding ideology, marketers are fast embracing the philosophy behind marketing concept as the option towards corporate goal achievement through customer satisfaction, (Chigozie, 2007).

Marketing means different things to different people, according to Okpara (2002) marketing is the individual or institutional activities designed to create customer satisfaction and relationship, by striving to make offers and acceptance, mutually easier and favourable. It is on the basis of this marketing concept orientation that Hunt (1983) defined marketing as a positive business activity, which establishes develops, and satisfies both customer needs and wants. It is worthy to note that one of the first formal statements on the marketing concept was made in 1957 by John B. McKitterick, the President of General Electric. He told an American Marketing Association meeting that the marketing concept was a customer oriented, integrated profit oriented philosophy of business, (Evan and Berman 1995).

Onah and Thomas (1993) viewed marketing concept as corporate State of mind under which management requires that all marketing functions should be integrated and company's policies built on this basic that customer needs are organized as of utmost importance. Essien (2006) opines that the capacity to profitability make the satisfaction of customers' needs central to every activity in a business organization is the essence of the marketing concept. According to him, marketing is an operational philosophy which clearly 
recognized that it is for the purpose of satisfying the customer that businesses exist, and that the continued existence of any business is, to some extent a measure of how that philosophy is practiced.

Anyanwu (1993) opines that marketing concept is most practiced in the developed and developing countries of the west. Its emphasis is on finding wants and filling them rather than creating products and selling them. He further described marketing concept as an idea which assumes that the sure way to achieving success in the market and for management to direct its effort at efficiently satisfying these wants at a profit to the organization. The marketing concept recognizes the veto power of the consumers in the market place, therefore, places premium on determining what the consumers actually want before creating and offering them the goods/ services. In this way, the concept offers opportunity to firms not only to make profit but also to satisfy their customers.

Agbonifoh (1998) in their contribution described the marketing concept as a management philosophy which emphasizes the achievement of an organization short and long term goals through the satisfaction of the customer and the harmonization and integration of all marketing activities as well as the marketing concept emphasizes on partnership between the customer and the marketers (business) for long term benefits. This is called relationship marketing which means staying in touch with people's changing needs and ensuring the company's ability to fill those needs with new product lines and marketing strategies. It is with this understanding that the organization crowns the customer as the "King" (Aleje, 2000).

\section{The Study Area and Its Unique Location}

Akwa Ibom State is one of the Thirty Six (36) states in the Nigeria Federation (see fig.1). It is Nigeria's $21^{\text {st }}$ State carved out of the former Cross River State by the government of General Ibrahim Babangida on September 23, 1987. She lies wholly within the tropics along the South-South corner of Nigeria and Gulf of Guinea and is located on latitude 4033' and 5053' North and longitude 7025' and 8025 East. Akwa Ibom State is situated on a land mass covering a total area of 8,412 square kilometers. Its dominant is green foliage of trees with shrubs and oil palm belt. Blessed with incredibly large deposits of crude oil and other natural and human resources, Akwa Ibom State is currently ranked number one oil producing state in Nigeria's political economy.

Akwa Ibom State is densely populated with a population of 3.92 million people (NPC,2006 ). Average population density is 350 inhabitants per square kilometer and 85 percent of the population lives in the rural areas. It shares boundaries with Abia, Cross River and Rivers States while the southern land mass is bounded by the Atlantic Ocean. Virtually every section of the state could be easily reached within an hour's drive from the state capital, Uyo. The state is made up of thirty-one (31) Local Government Areas.

Akwa Ibom is the only state in Nigeria that is served by three export free zones, which means triple benefits for investors. There is an export processing zone at Ikot Abasi, Akwa Ibom State. The state also falls within the catchments area for Calabar export processing zone and the oil and gas free zone in Port Harcourt. Because the site is well-positioned midway between the port cities of Calabar and Port Harcourt, Akwa Ibom State land has unlimited access to the World whether by land, or by sea. With the commencement of daily commercial flights at the ultra-modern Akwa Ibom International Airport, Okobo, Akwa Ibom State can also be reached by air. Indeed, the state has become part of Nigeria's gateways to the countries of Central Africa like Cameroun, Gabon, Central African Republic, Equitorial Guinea and Congo DR (AKS, 2013).

Evidently, Akwa Ibom is also considered the most peaceful state in the Niger Delta region of Nigeria, coupled with better economic and social conditions necessary for hotels and tourism business to thrive.

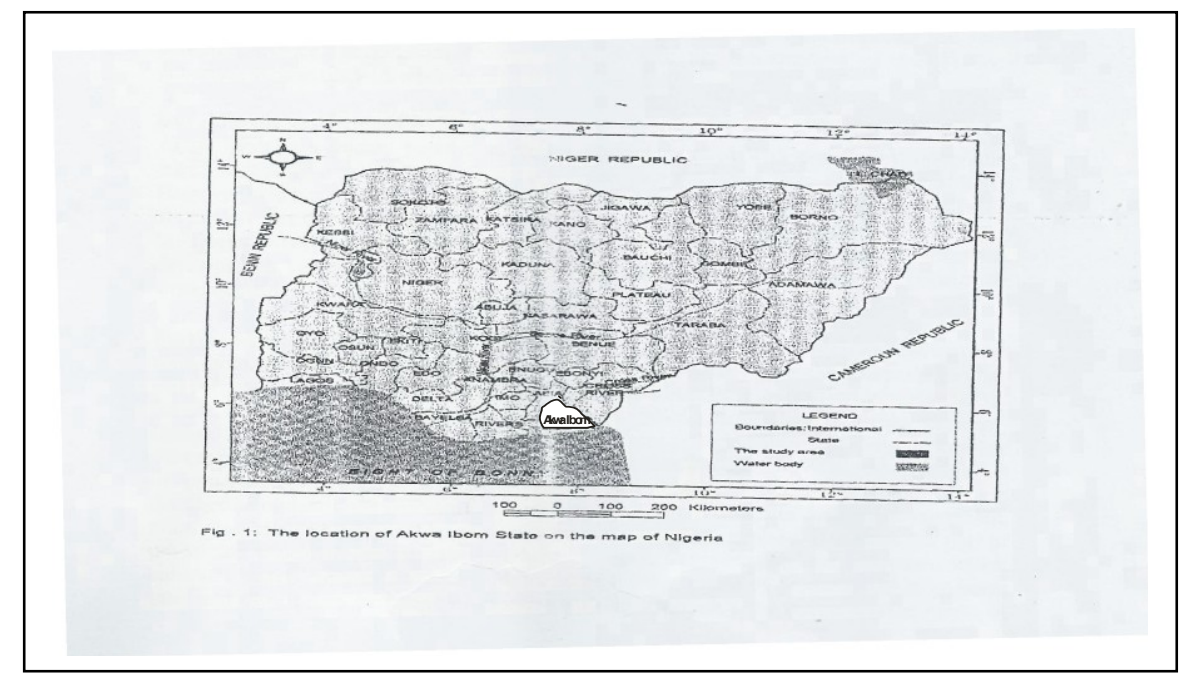


Source: Ibok and Daniel (2013)

\section{Marketing Mix Variables in the Hospitality and Tourism Industry}

Product: The product is very important and crucial to marketers because the purpose of marketing is to identify the needs and wants of the target markets and produce product or render service to satisfy them. Based on this Busch and Houston (1985) defined product as anything capable of satisfying a consumer need or want. Kotler (1980) also defined a product as anything that can be offered to a market for attention, acquisition or consumption. It includes physical goods, services, ideas, persons or places and organizations. Hotels get into a lot of trouble by paying more attention to their physical structures and equipment than to the services produces by these products. These has often resulted In hostels (hospitality business) enjoying reasonable patronage at the introductory stage and get stunted within a very short time,(Chigozie, 2007).

Price:- Price is a key marketing mix element and it is a major competitive weapon in a market place. Hospitality and tourism business in determining the needs and wants of the prospective customers can use price as a weapon of success in a competitive market place. For the purpose of this paper, price is the money paid in exchange for a product (goods or services). It is a value expressed in terms of money. It is also described as the marketing value of an item (services in case of the hospitality and tourism industry). Thus, the operators of hotels and tourism business can use pricing strategy to achieve its objectives. They can increase or decrease the price as the case may be to achieve the organizational objective.

Promotion:- In hospitality and tourism industry the need and want of the consumer identified using the application of marketing concept can be easily communicated to the target market through the application of various elements of promotion, namely advertising, personal selling, sales promotion, publicity and public relations. For instance, if one embarks on tour or holiday outside his or her residential area, and he needs a hotel accommodation or recreational centre, he may be aware of the facilities, products, or service available in a particular hotel or recreation centre through the activities of promotion either through electronic or print media. This assists the organization to an extent to achieve its goals.

Place:- In marketing, the location of any business is very important to the marketing practitioners because somehow it contributes immensely to the achievement of marketing objective. In hospitality and tourism industry, location of particular hotel or recreation centre adds value to needs satisfaction strategies adopted by the recreation or hotel. Is the environment quiet, conductive or crowding? All necessary environment factors must be taken into consideration before the location of hotel business or recreational area is chosen.

The understanding of the above named marketing elements is essential for the success of the operators of the hospitality and tourism business in the market place. Its application as far as marketing concept is concerned is crucial to create customer satisfaction value.

\section{Hospitality and Tourism Establishments in Akwa Ibom State}

Hospitality and Tourism industry has become the largest and one of the lucrative businesses with undeniable great returns if the needs of the patronages are carefully identified to ensure repeat patronages. The State Government in order to sensitize the operators, established the Akwa Ibom State Hotels and Tourism Board with the following mandates

i. Registration and inspection of Hospitality and Tourism enterprises in the state.

ii. To provide unadulterated information and statistics that would aid efficient planning and development.

iii. To ensure that standards required are met in terms of facilities and services at all hospitality outfits as specified by the Nigeria Tourism Development Corporation (NTDC) for purposes of grading and classification.

Table 1. Some Major Hospitality outfits in Akwa Ibom State

\begin{tabular}{|c|c|c|c|}
\hline \\
\hline $\mathbf{S} / \mathbf{N}$ & HOTEL & LOCATION & FACILITY/PRODUCT \\
\hline 1. & $\begin{array}{l}\text { Le Meridien Hotel and Golf } \\
\text { Resort }\end{array}$ & Nwaniba, Uruan & $\begin{array}{l}163 \text { Tastefully Furnished Rooms, Suites } \\
\text { and Chalets all with private terraces, } 18- \\
\text { hole golf course, jetty for boat cruise, } 4 \\
\text { Restaurants, } 3 \text { Bars, } 10 \text { Meeting Rooms, } \\
650 \text { Capacity Conference Hall, Business } \\
\text { Centre, Gym, indoor and outsports } \\
\text { facilities, swimming pool, internet } \\
\text { access etc. Serve Local, Continental, } \\
\text { African, Asian Dishes etc. }\end{array}$ \\
\hline 2 & Agatha Garden Guest House & $\begin{array}{l}\text { Plot 69B, F-Line, Ewet Housing } \\
\text { Estate, Uyo }\end{array}$ & $\begin{array}{l}23 \text { Rooms Self Contained bungalows, } \\
\text { Conference Hall,Restaurant Serves local } \\
\text { and continental dishes. }\end{array}$ \\
\hline
\end{tabular}




\begin{tabular}{|c|c|c|c|}
\hline 3 & Amity Hotels Ltd & $\begin{array}{l}\text { D Line, Ewet Housing Estate, } \\
\text { Uyo }\end{array}$ & $\begin{array}{l}21 \text { Well furnished Rooms, Large } \\
\text { Conference Hall, Restaurant, Cybercafé, } \\
\text { Bar }\end{array}$ \\
\hline 4 & Aqua Resort Ltd & $\begin{array}{l}3 \text { Ekpe Nkereuwem Close, Ewet } \\
\text { Housing Estate, Uyo. }\end{array}$ & $\begin{array}{l}13 \text { well furnished Rooms, Big } \\
\text { Restaurant, Bar, internet, serves local } \\
\text { and continental dishes. }\end{array}$ \\
\hline 5 & Bells Cafeteria (fast food) & $\begin{array}{l}\text { Plot 5, Unit F, Ewet Housing } \\
\text { Estate, Uyo. }\end{array}$ & $\begin{array}{l}\text { Serves local, African and continental } \\
\text { dishes, children's play corner, provides } \\
\text { indoor and outdoor catering services. }\end{array}$ \\
\hline 6 & Beton Cooks & 75c Ikot Ekpene Road, Uyo. & $\begin{array}{l}\text { Fast food joint with large restaurant, } \\
\text { offers snacks and local dishes, inside } \\
\text { Bar, Restaurant, Sit-Out Bar, Ice Cream } \\
\text { stand. }\end{array}$ \\
\hline 8 & Food Affairs Ltd & 15 Udotung Ubo Street, Uyo & $\begin{array}{l}30 \text { sitting capacity conference hall, } \\
\text { children play corner, } 6 \text { sitting capacity } \\
\text { private dinning, } 40 \text { sitting capacity } \\
\text { restaurant, serves snacks and local } \\
\text { dishes. }\end{array}$ \\
\hline 9 & Gold Ribbon & $\begin{array}{l}48 \text { Esuene Street, Abak Road, } \\
\text { Federal Housing, Uyo. }\end{array}$ & $\begin{array}{l}12 \text { Royale Rooms, Restaurant, } \\
\text { Executive bar, Laundry. }\end{array}$ \\
\hline 10 & Green Park Hotel \& Suites & $\begin{array}{l}3 \text { Ekereuke Street, Mbiabong } \\
\text { Etoi, Uyo. }\end{array}$ & $\begin{array}{l}16 \text { Rooms Restaurant, Conference Hall, } \\
\text { Bar. }\end{array}$ \\
\hline 11 & Legacy Concerns Ltd & $\begin{array}{l}\text { Plot 6, Unit G, Ewet Housing } \\
\text { Estate, Uyo. }\end{array}$ & $\begin{array}{l}16 \text { Rooms, Restaurant, Bar, Internet } \\
\text { Services, serves African and continental } \\
\text { cuisines. }\end{array}$ \\
\hline 12 & Samlaw Hotel & $\begin{array}{l}5 \text { Ebetaya Street, off IBB Way, } \\
\text { Uyo }\end{array}$ & $\begin{array}{l}19 \text { Rooms, Bar, Restaurant, Conference } \\
\text { Hall }\end{array}$ \\
\hline 13 & Pinnacle Premium Suites & Edet Akpan Avenue, Uyo & $\begin{array}{l}10 \text { Exquisitely furnished Rooms, } \\
\text { Swimming Pool, Garden Bar, Indoor } \\
\text { catering services, Restaurant serves } \\
\text { African and continental cuisines }\end{array}$ \\
\hline 14 & Crunches Fried Chicken & 142 Aka Road, Uyo & $\begin{array}{l}\text { Fast food Outlet with Large Restaurant } \\
\text { on } 2 \text { floors, Children play section, } \\
\text { serves snacks and local dishes, outdoor } \\
\text { space/garden for events. }\end{array}$ \\
\hline 15 & Eemjm Hotels \& Suits Ltd & 47 Dominic Utuk Avenue, Uyo. & $\begin{array}{l}70 \text { tastefully-furnished Rooms, Gym, } 2 \\
\text { restaurants, swimming pool with Bar, } \\
\text { outdoor games, internet, conference } \\
\text { facilities, Airline Desk. Serves local and } \\
\text { continental dishes. }\end{array}$ \\
\hline 16 & Dignity Hotel & 55 Faith Road, Uyo & $\begin{array}{l}24 \text { Rooms, multipurpose conference } \\
\text { hall, sit-out Bar, Restaurant, Inside Bar, } \\
\text { Minishop }\end{array}$ \\
\hline 17 & Dollar Restaurant & 15 Oron Road, Uyo & $\begin{array}{l}\text { Well-furnished and Neat, fully Air- } \\
\text { conditioned, Restaurant seats } 50-60 \\
\text { people. Serves wide variety of local } \\
\text { dishes and delicacies. }\end{array}$ \\
\hline 18 & Angellyne Guest House & 6 Convent Close, Abak & $\begin{array}{l}16 \text { well-furnished Rooms, Restaurant, } \\
\text { Bar, Garden sit-out, Conference Hall }\end{array}$ \\
\hline 20 & De Leisure Lodge & 9 Oku Abak Lane, Abak & 7 Rooms, Restaurant, Bar \\
\hline 21 & The Lily Home & Uyo Road, Ediene Abak & $\begin{array}{l}16 \text { Rooms, Restaurant, Bar. Serves local } \\
\text { dishes }\end{array}$ \\
\hline 22 & $\begin{array}{l}\text { Royalty Hotel and } \\
\text { Recreations Ltd }\end{array}$ & 74/76 Eket -Oron Road, Eket & $\begin{array}{l}30 \text { well-furnished Rooms, Restaurant, } \\
\text { Bar, Cyber Café, Training Rooms, } \\
\text { Clinic, Conference facilities, Gym, } \\
\text { meeting rooms, shops serves local and } \\
\text { continental dishes. }\end{array}$ \\
\hline 23 & Sphinx Hotel & 2 Ekpe Close, Eket & $\begin{array}{l}12 \text { well-furnished Rooms with } \\
\text { customized toiletries, Bar, Restaurant } \\
\text { serves local and continental dishes }\end{array}$ \\
\hline 24 & Villa Marina Hotel & 16 Marina Avenue, Eket & $\begin{array}{l}133 \text { Exquisite Rooms, Bar, Business } \\
\text { Centre, Cyber Café, floral Bar, outside } \\
\text { Bar, Banquet Hall, Swimming Pool } \\
\text { Gym, Restaurant, Internet. Spot } \\
\text { facilities, indoor/outdoor games. Serves } \\
\text { local and continental dishes. }\end{array}$ \\
\hline 25 & Parosa Motel & 12 Market Road, Ibesikpo & $\begin{array}{l}12 \text { Rooms, Conference Hall, Bar, } \\
\text { Restaurant. }\end{array}$ \\
\hline 26 & Samtex Forest Hotels & 40 Hospital Road, Ikot Abasi & 7 Rooms, Banquet Hall, Restaurant. \\
\hline 27 & Anibeto Palace Hotel & $\begin{array}{l}1 \text { Ephraim Essien Street, Ikot } \\
\text { Ekpene }\end{array}$ & $\begin{array}{l}14 \text { Rooms, Restaurant, sit-out Bar, } 50 \\
\text { capacity conference Room }\end{array}$ \\
\hline 28 & Sernue Global Lodge & 8 Adadiaha Road, Ikot Ekpene & 17 Rooms, Bar \\
\hline 29 & Tropical Guest House & 80, Okop Eto Road, Ikot Ekpene & 22 Rooms, Bar, Restaurant, Dinning, \\
\hline
\end{tabular}


Appllication Of Marketing Concept In The Hospitality And Tourism Industry In Akwa Ibom State,

\begin{tabular}{|l|l|l|l|}
\hline & & & Multi-purpose Hall, Presidential Bar \\
\hline 30 & Skycap Accommodations & 22 Nsikak Eduok Avenue, Uyo. & $\begin{array}{l}\text { 26 Rooms, Restaurant for 24 Guests, } \\
\text { Bar, Kitchen, Laundry, Conference Hall } \\
\text { for 100 Guests, 100KVA Generator }\end{array}$ \\
\hline 31 & Excel Towers & Mkpat Enin & $\begin{array}{l}\text { 20 Rooms, 2 Bars, 50 Seats capacity } \\
\text { Restaurant, Reception Hall seat } 80- \\
\text { 100. Serves local dishes. }\end{array}$ \\
\hline 32 & Bakibum Beach Hotels & Oron Beach, Oron & $\begin{array}{l}\text { 30 Rooms, Conference Hall, Sea-view } \\
\text { Penthouse, Night/Dancing Club, sit-out } \\
\text { Bar }\end{array}$ \\
\hline 33 & Villademia Nig. Enterprises & Imohowo Lane, Oron & 20 Rooms, outside Bar with shop \\
\hline 34 & Splash Dance Bar & $\begin{array}{l}3 \text { Eyetong Road, } \\
\text { Oron }\end{array}$ & $\begin{array}{l}\text { Large Bar/Restaurant, Casino/Dance } \\
\text { Club, Indoor Games, outdoor Event } \\
\text { place/games. }\end{array}$ \\
\hline 35 & Edinburgh Hotel & $\begin{array}{l}\text { 15 Inwang Udo Street, off Uyo } \\
\text { Road, Etinan }\end{array}$ & \begin{tabular}{l} 
10 Rooms, Bar, Restaurant \\
\hline
\end{tabular} \\
\hline
\end{tabular}

Source: AKS (2013)

Table 2. Some Major Tourism Sites in Akwa Ibom State

\begin{tabular}{|l|l|l|l|}
\hline S/N & SITE & LOCATION & FACILITY \\
\hline 1 & Ibom Plaza & Uyo & $\begin{array}{l}\text { An inland tourist resort planted at the Centre Of Uyo, the State } \\
\text { Capital. Art piece adorned with dazzling selections of beautiful, } \\
\text { exotic and ornamental plants, water fountains and aesthetic } \\
\text { lightings. }\end{array}$ \\
\hline 2 & Beaches/Waterfronts & $\begin{array}{l}\text { Utaewa, Ibeno and } \\
\text { Oron }\end{array}$ & $\begin{array}{l}\text { Endowments with vast stretches of boundless rivers and ocean } \\
\text { beaches providing varied opportunities for swimming, skiing, sun } \\
\text { bathing, nature watching and other water sports. }\end{array}$ \\
\hline 3 & $\begin{array}{l}\text { Mary Slessor Memorial } \\
\text { Cairn }\end{array}$ & $\begin{array}{l}\text { Use Ikot Oku, Ibiono } \\
\text { Ibom }\end{array}$ & $\begin{array}{l}\text { Where the Late Missionary, Mary Slessor built her residence. The } \\
\text { imposing cairn is raised to the evergreen memory of Mary Mitchell } \\
\text { Slessor, a Scottish Missionary whose personal sacrifices, religious, } \\
\text { fervor, commitment and advocacy pioneered a new brand of } \\
\text { Christianity, particularly stopping the killing of twins in Nigeria. }\end{array}$ \\
\hline 4 & $\begin{array}{l}\text { Museums and } \\
\text { Antiquities }\end{array}$ & $\begin{array}{l}\text { The National Museum in Oron established in 1959 has over 600 } \\
\text { artifacts. National Museum in Uyo contains mainly relics of Akwa } \\
\text { Ibom State creation and other important artifacts of the people of } \\
\text { the state. }\end{array}$ \\
\hline
\end{tabular}

Source: AKS (2013)

\section{Discussion of Findings}

In Akwa Ibom State, Nigeria, there are one hundred and Twelve (112) registered Hotels and Tourism Centres cut across the thirty -one (31) local government areas of the state (AKS, 2013). Tables shown above and findings showcase that most of the hospitality industry, in the state embraces the marketing concept in running their businesses. This is evidence in the facilities/products available as indicated in tables to satisfy the needs/wants of their customers.

The implication is that the actual needs/wants of the customers is being identified and provided by the operators to attract continuous repeat patronages.

However, the Hospitality and Tourism industry in Akwa Ibom State is affected with some hindrances such as non-employment of expertise in the field of marketing to manage the affairs of their businesses, lack of technical know-how, inadequate funds to run the business, inability of some of the operators to identify what actually are the customers needs etc.

\section{Conclusion}

The analysis presented in this paper shows that the effective application of marketing concept in the hospitality and tourism industry would assist the operators in attainment of their organizational objectives. Specifically, knowledge of the consumer need and wants will enable the operators give customer satisfaction in order to guarantee repeat patronages.

To overcome challenges face in the business world through intensive competition, hospitality and tourism business operators need to embrace marketing concept and apply it effectively to have competitive advantage.

RECOMMENDATIONS: Based on the findings, the paper therefore makes the following recommendations.

1) The hospitality and tourism industry should apply the marketing concept effectively to have an edge over its competitors.

2) They should embrace the concept for a better economic gain.

3) Experts in the field of marketing should be employed by hospitality and tourism industry to ensure effective and efficient application of the marketing concept. 
4) The operators of the hospitality and tourism industry should participate in seminars and workshops organize on application of marketing concept for better understanding of the concept.

\section{References}

[1]. AKS (2013) Akwa Ibom State of Nigeria: Hotels and Tourism Directory.

[2]. Adeyemo, W . B. (2005): Hospitality Marketing, Lagos, Adeyz Consulting and Publishers.

[3]. Agbonifoh, B. l (1998): Marketing in Nigeria, Concept Principles and Decision, Aba, Afritower Ltd, Publishers.

[4]. Aleje, A . O. (2000): Enhancing Marketing Performance in This Millennium through Total Quality Management (TOM), Marketing Journal vol.5, No.2.

[5]. Anyanwu, A.(1993): Dimension of Marketing, Okigwe, Imo State, Avan Global Publications.

[6]. Busch, P. S. and Houston, M. J. (1985): Marketing Strategic Foundation, Homewood, Illinois, Richard D. Irwin Inc.

[7]. Chigozie, O. U. (2007): Application of Marketing Concept in the Hospitality Industry, International Research Journal for Development, Vol.9, No.1

[8]. Essien, E. E. (2006): Entrepreneurship; Concept and Practice, Uyo, Abaam Publishing Company.

[9]. Evan, J. R and Berman, B. (1995): Principles of Marketing, New Jersey, Prentice Hall Inc.

[10]. Hunt, D. S. (1983 ): General Theories and the Fundamental of Marketing, Journal of Marketing Vol.2, No.5

[11]. Ibok, E, and Daniel, E. (2013). The Impact of Rural Roads and Bridges on the Socio-Economic Development of Akwa Ibom State, Nigeria: An Evaluation. Global Journal of Political Science and Administration, Vol 1, No. 1, pp. 27-36.

[12]. Kotler, P. (1980): Marketing Management, Analysis, Planning and Control,Englewood Cliffs, Prentice Hall Inc.

[13]. Nwidum, F. (2007): Hospitality and Tourism Industry in National Development; The Role of the Personal Secretary, International Research Journal for Development, Vol.9, No.1.

[14]. NPC (2006). National Population Commission: Census Report

[15]. Okpara, G. (2003): Contemporary Marketing: Tropical and Tropicalized, Enugu, John Jacob's Classic Publishers Ltd.

[16]. Onah, J.O, and Thomas, J. M. (1993): marketing management, Urvowulu-Obosi, Nigeria, Pacific Publishers Ltd. 